\title{
The Life of Simeon of the Olives
}

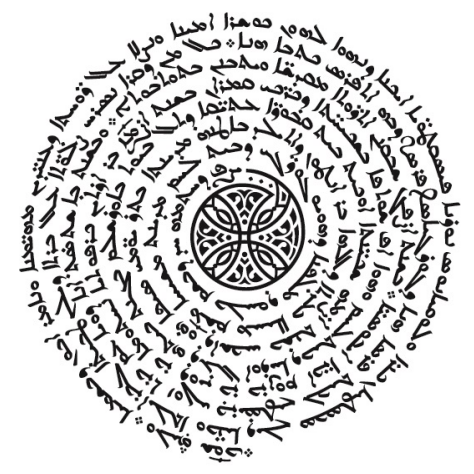




\section{Texts from Christian Late Antiquity}

66

TeCLA (Texts from Christian Late Antiquity) is a series presenting ancient Christian texts both in their original languages and with accompanying contemporary English translations. 


\title{
The Life of Simeon of the Olives
}

\author{
An entrepreneurial saint \\ of early Islamic North Mesopotamia
}

By

Robert G. Hoyland

Sebastian P. Brock

Kyle B. Brunner

Jack Tannous

OR OREIAS

2021 
Gorgias Press LLC, 954 River Road, Piscataway, NJ, 08854, USA

www.gorgiaspress.com

Copyright (C) 2021 by Gorgias Press LLC

All rights reserved under International and Pan-American Copyright Conventions. No part of this publication may be reproduced, stored in a retrieval system or transmitted in any form or by any means, electronic, mechanical, photocopying, recording, scanning or otherwise without the prior written permission of Gorgias Press LLC.

2021

a

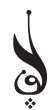

ISBN 978-1-4632-4346-3

ISSN 1935-6846

\section{Library of Congress Cataloging-in-Publication} Data

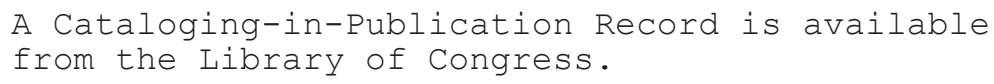

Printed in the United States of America 